\title{
Corporate Social Responsibility in Supply Chain Management: Thai Auto Parts Industry
}

\author{
Thanyaphat Muangpan* \\ Mana Chaowarat
}

Faculty of Logistics

Burapha University

Chonburi, Thailand

\begin{abstract}
Corporate social responsibility (CSR) is a key operation to achieve the important goal of business sustainability. The UN Global Compact developed the ten principles of CSR with the aim of achieving corporate sustainability which will bring about long-term benefits for the operation of the business. Also, supply chain management (SCM) has increased in importance as the key operation for developing value added for increased customer satisfaction and reduced business costs; however, the management also has an effect upon the environmental and social surroundings. Therefore, the integration of CSR in SCM needs to be developed to create operational guidelines for best practice within companies throughout the industrial sector. This paper aims to test the conceptual framework which is reviewed through the five main dimensions from ten principles of CSR and the SCOR model of SCM in order to develop the principle model of CSR in SCM using a case study in the Thai auto parts industry. Survey research is applied in this study using questionnaires. Inferential statistical analysis using the partial least square of structural equation modeling was used for the data analysis involving study respondents whose work is related to the ISO and SCM departments. The findings, confirmatory results of the conceptual framework, and structural equation model of CSR in SCM are presented with five main dimensions and 31 indicators with the aim of achieving corporate sustainability. The industrial sector and the companies within it can apply these guidelines to establish sustainable operational strategies and sustainable policies to create sustainable operations for the company management aiming for business sustainability.
\end{abstract}

Keywords: Corporate Social Responsibility (CSR), Supply Chain Management (SCM), Structural Equation Model (SEM), Sustainability.

\section{Introduction}

Environmental problems have affected many countries through carbon dioxide emissions. By the mid- $21^{\text {st }}$ century, the carbon dioxide level is expected to double (United Nations Environment Programme, 2011). This would also controls the maximum amount of carbon dioxide $\left(\mathrm{CO}_{2}\right)$ that can be emitted into the atmosphere while staying within safe temperature limits beyond 2020 (United Nation Environment Programme, 2016). In most countries, the main cause of carbon dioxide emissions is emitted from the manufacturing of industrial procedure burning, and this sector has focused on production capacity to respond to market demand. Also, supply chain management (SCM) in industry is favorable to operate to add value in the chain and company (Andersen \& Skjoett-Larsen, 2009;Bak\&Boulocher-Passet, 2013). The goal of SCM is to minimize total cost, maximize customer satisfaction, and add value to the product chain that used a variety of natural resources and energy while causing minimal waste and pollution to the community and the environment (Xia \& Tang, 2011;Aigner \& Lloret, 2013). This pollution problem can be solved by sustainable supply chain management (United Nations Environment Programme, 2014).

In regard to the sustainability concept, corporate social responsibility (CSR) is an interesting theory for companies that apply to business practice involving benefits to society and the environment (Bevilacqua, Ciarapica, \& Giacchetta, 2012; Morana, 2013). CSR is explained with two main dimensions which are the environmental dimension by reducing environment effects and the social dimension by developing socially-friendly companies (Wu \&Zhi,2016;Mani, Gunasekaran, \& Delgado, 2018). The UN Global Compact developed the ten principles of corporate sustainability beginning with many international developing guidelines for developing a company to achieve business sustainability (UN global compact, 2017). Also, Thailand needs to conform to its commitments under various cooperation frameworks and strengthen its resilience through development of its economic and social capital (National Economic and Social Development Board, 2015; United Nations Development Programme - UNDP Thailand, 2015). 
This research was applied with five main dimensions from the ten principles corporate responsibility by the UN global compact and integrated with SCM concept. These five dimensions presenting, four main dimensions defined fundamental responsibilities in the areas of human rights, labor, environmental, anti-corruption, and one main dimension defined preferable responsibilities on friendly technologies into the strategies, policies and procedures for sustainable companies. Furthermore, SCM is explained with the SCOR model which includes five keys for company strategy including planning, source, make, delivery and return. The main advantages of CSR in SCM are the improvement of supplier collaboration, higher quality of products, meeting customers' expectations, and new market opportunities (CSR compass 2016).The purpose of this paper is to test the conceptual framework of CSR in SCM and develop a principle model of CSR within SCM. The automotive industry is used in this case study, which is a significant contribution to the Thailand's economy accounting for $10 \%$ of the nation's gross domestic product (GDP) (Thailand Board of Investment, 2015).

\section{The conceptual framework of CSR in SCM}

The dimensions and indicators of CSR in SCM are reviewed with two data sources which are the academic literature and CSR documents of companies. Content analysis is the instrument to analyze data from these two sources, and the summary covers the five main dimensions from ten principles of CSR; four main dimensions defined fundamental responsibilities in the areas of human rights, labor, environmental, anti-corruption, and one main dimension defined preferable responsibilities on friendly technologies(United Nations Global Compact, 2018) as shown in Table 1.These five main dimensions within SCOR model is unique in that it links business processes, metrics, and practices which include the five main elements that are displayed by plan, source, make, delivery and return in chain (APICS, 2017; Wisner, Tan \& Leong, 2012;Hugos, 2011; Hernandez \& Melis, 2018).

Figure 1 presents the five main dimension of CSR in SCM namely, CSR in the plan, CSR in procurement (source), CSR in production (make), CSR in transportation (delivery), and CSR in reverse logistics (return). The indicators of each dimension are specified by the five key indicators that must be considered for business strategies, sustainable policies, process procedures, and building a culture of integrity. This framework is a guideline for operational planning to develop the CSR in SCM towards company sustainability. This framework of CSR in SCM is needed to confirm the concept by respondents in related files for testing and developing the foundational model from the case study.

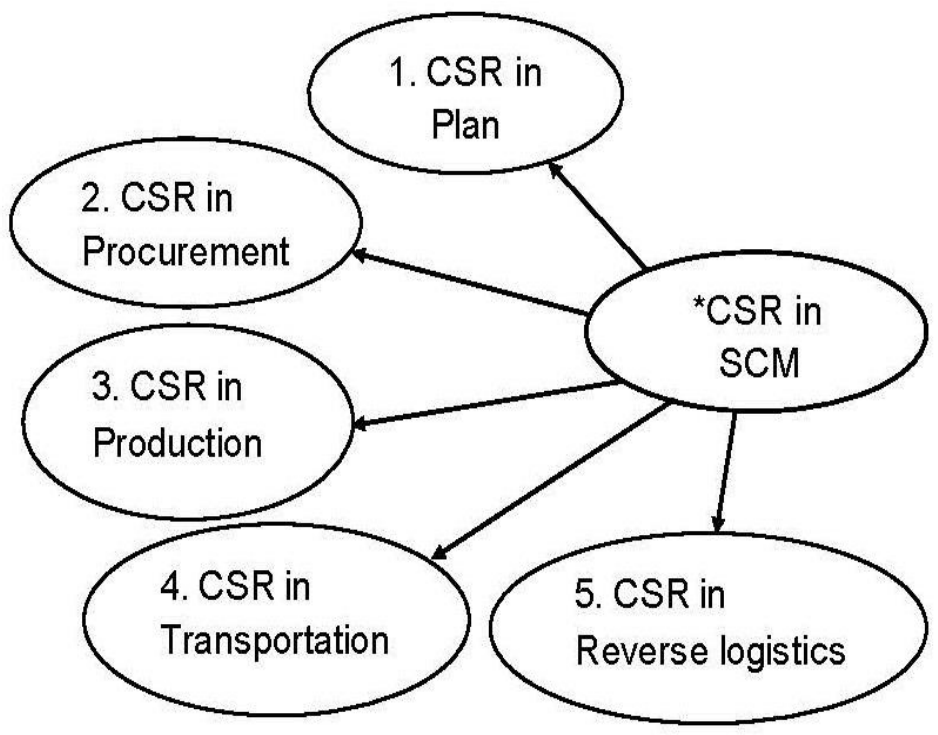

Figure 1 The conceptual framework of CSR in SCM 


\section{Table 1. Indicators and dimensions of CSR}

\begin{tabular}{|c|c|}
\hline Dimensions & Indicators \\
\hline 1. CSR in Plan & $\begin{array}{l}\text { C 1.1 SCM activities planning in consideration to human rights. } \\
\text { C } 1.2 \text { SCM activities planning by eliminating compulsory labor and } \\
\text { child labor. } \\
\text { C } 1.3 \text { SCM activities planning by reducing environmental effects. } \\
\text { C } 1.4 \text { SCM activities planning by using friendly technologies. } \\
\text { C } 1.5 \text { SCM activities planning by resisting corruption. }\end{array}$ \\
\hline 2. CSR in & C 2.1 Procurement practice having procurement justice \\
\hline Procurement & $\begin{array}{l}\text { C } 2.2 \text { Procurement process by selecting the suppliers that eliminate } \\
\text { compulsory labor and child labor. } \\
\text { C } 2.3 \text { Procurement process by selecting green suppliers. } \\
\text { C } 2.4 \text { Procurement management by selecting friendly-technology } \\
\text { suppliers. } \\
\text { C } 2.5 \text { Procurement operation by resisting corruption. }\end{array}$ \\
\hline 3. CSR in Production & $\begin{array}{l}\text { C 3.1 Production practice with employees' rights } \\
\text { C 3.2 Production process by eliminating compulsory labor and child } \\
\text { labor. } \\
\text { C 3.3 Production process by reducing environmental effects. } \\
\text { C 3.4 Production management by using friendly technologies. } \\
\text { C 3.5 Production operation by resisting corruption. }\end{array}$ \\
\hline $\begin{array}{l}\text { 4. CSR in } \\
\text { transportation }\end{array}$ & $\begin{array}{l}\text { C 4.1 Transportation practice with employees' rights } \\
\text { C 4.2 Transportation process by eliminating compulsory labor and } \\
\text { child labor. } \\
\text { C } 4.3 \text { Transportation process by reducing environmental effects. } \\
\text { C 4.4 Transportation management by using friendly technologies. } \\
\text { C 4.5 Transportation operation with resisting corruption. }\end{array}$ \\
\hline $\begin{array}{l}\text { 5. CSR in Reverse } \\
\text { Logistics }\end{array}$ & $\begin{array}{l}\text { C 5.1 Reverse logistics practice with ethical trading } \\
\text { C 5.2 Reverse logistics process by eliminating compulsory labor and } \\
\text { child labor. } \\
\text { C 5.3 Reverse logistics process by reducing environmental effects. } \\
\text { C 5.4 Reverse logistics management by using friendly technologies. } \\
\text { C 5.5 Reverse logistics operation with resisting corruption. }\end{array}$ \\
\hline *CSR in SCM & $\begin{array}{l}\text { CSR 1. Improving suppliers' collaboration } \\
\text { CSR 2. Improving product quality } \\
\text { CSR 3. Improving customers' expectations } \\
\text { CSR 4. Reducing the SCM risk } \\
\text { CSR 5. Maintaining employees' and customers' relationships } \\
\text { CSR 6. Creating new markets }\end{array}$ \\
\hline
\end{tabular}

Methodology

The survey research is applied in this study with questionnaires. Testing of the questionnaire was conducted using the index of consistency (IOC) and Cronbach's alpha. The questionnaire testing was sent to five experts in the supply chain and sustainability management field in order to examine the content and construct validity of each item and decide the consistency of the questionnaire with scores. Moreover, the questionnaire with valid items was again examined for reliability through a pilot survey which thirty datasets of the target sample were tested. The Cronbach's alpha score for the reliability of the questionnaire was 0.852 , indicating that the questionnaire was appropriate.

This study is collected data from the respondents in Thai auto parts companies that are certified in ISO/TS 16949 and managing CSR as case study companies in Amata Nakorn Chonburi, Thailand. These population selecting with a total of 90 companies and can be defined as respondents who are working in positions related to CSR and SCM which directly respond to operate CSR in SCM. The total numbers of populations are infinite. Therefore the sample size is calculated using the Yamane's formula (Singh \& Masuku, 2014). The maximum number of sample size is taken to be sample size in this research. Therefore, more than 100 officers (Precision levels $\pm 10 \%$ ), as shown in Table 2, are randomly selected from this population using the cluster sampling method. 
Table 2 Sample Size for $\pm 5 \%$ and $\pm 10 \%$ Precision Levels

\begin{tabular}{|c|c|c|}
\hline \multirow{2}{*}{$\begin{array}{c}\text { Size of } \\
\text { population }\end{array}$} & \multicolumn{2}{|c|}{ Sample size (n) for precision (e) } \\
\cline { 2 - 3 } & $\mathbf{\pm 5 \%}$ & $\mathbf{\pm 1 0 \%}$ \\
\hline 500 & 222 & 83 \\
\hline 1,000 & 286 & 91 \\
\hline 2,000 & 333 & 95 \\
\hline 3,000 & 353 & 97 \\
\hline 4,000 & 364 & 98 \\
\hline 5,000 & 370 & 98 \\
\hline 7,000 & 378 & 99 \\
\hline 9,000 & 383 & 99 \\
\hline 10,000 & 385 & 99 \\
\hline 15,000 & 390 & 99 \\
\hline 20,000 & 392 & 100 \\
\hline 25,000 & 394 & 100 \\
\hline 50,000 & 397 & 100 \\
\hline 100,000 & 398 & 100 \\
\hline$>\mathbf{1 0 0 , 0 0 0}$ & 400 & $\mathbf{1 0 0}$ \\
\hline
\end{tabular}

The questionnaires were distributed to a sample totaling 248 respondents which included $53.2 \%$ females and $46.8 \%$ males. The respondents consisted of $46 \%$ of $20-29$ year olds, and $54 \%$ of 30-39 year olds. The educations of the respondents indicated $34.3 \%$ with high school diplomas, $59.7 \%$ with bachelor's degrees, $2.8 \%$ with master's degrees, and $3.2 \%$ with doctoral degrees. Most respondents were administrators at $71.8 \%$, followed by operational managers at $28.2 \%$, middle managers at $13.7 \%$ and top managers at $3.6 \%$. This administrators respondents are direct respond participate in create sustainable operations, and all managers participate in guidelines to establish sustainable operational strategies and sustainable policies.

Inferential Statistics Analysis using the partial least square of structural equation model (PLS-SEM) with bootstrap algorithm was applied to analyze the questionnaires. This analysis is to determine the importance of indicators explaining to five main dimensions and the important indicators affecting the management of CSR in SCM (Kelloway, 2015; Blunch, 2013). Moreover, the five hypotheses are tested the drive of indicators for the relationship set among the dimensions. This statistical method was analyzed using the Smart PLS program version 3 (Ringle, Christian, Wende \& Becker, 2015).

\section{The findings and discussion}

The model of CSR in SCM is shown in figure 2, and results of the confirmatory factor analysis and reliability measures is shown in tables 3-5, Cronbach's alpha coefficient should exceed the common threshold of 0.5. Factor loadings should be greater than 0.5 . Composite reliability exceeds the common threshold of 0.6. The results show that some factor loadings are less than 0.5, indicating that the dimensions are not well explained by those indicators. Loading values of the indicators are in five dimensions. It can be seen that the loadings are less than 0.5. This indicates that the indicators explain moderately well their own dimensions. Moreover, from the descriptive statistics, we can see that the importance levels of the indicators to the dimension are at the intermediate level.

The model of CSR in SCM is to test the conceptual framework for developing the principle model of CSR in SCM. There are five hypotheses which drive the indicators to set the relationship among the dimensions as follows:

$\mathrm{H} 1$ : The CSR in planning $(\mathrm{C} 1)$ is positively related to CSR in SCM

$\mathrm{H} 2$ : The CSR in procurement (C2) is positively related to CSR in SCM

H3: The CSR in production (C3) is positively related to CSR in SCM

H4: The CSR in transportation (C4) is positively related to CSR in SCM

H5: The CSR in reverse logistics (C5) is positively related to CSR in SCM

The structural equation model is shown in Figure 2 . The $\mathrm{R}^{2}$ is 0.381 indicating that the model is moderately strong. The model of CSR in SCM is shown as follows:

$* \mathrm{CSR}$ in $\mathrm{SCM}=0.150 \mathrm{C} 1+0.230 \mathrm{C} 2+0.103 \mathrm{C3}+0.136 \mathrm{C} 4+0.184 \mathrm{C} 5$ 


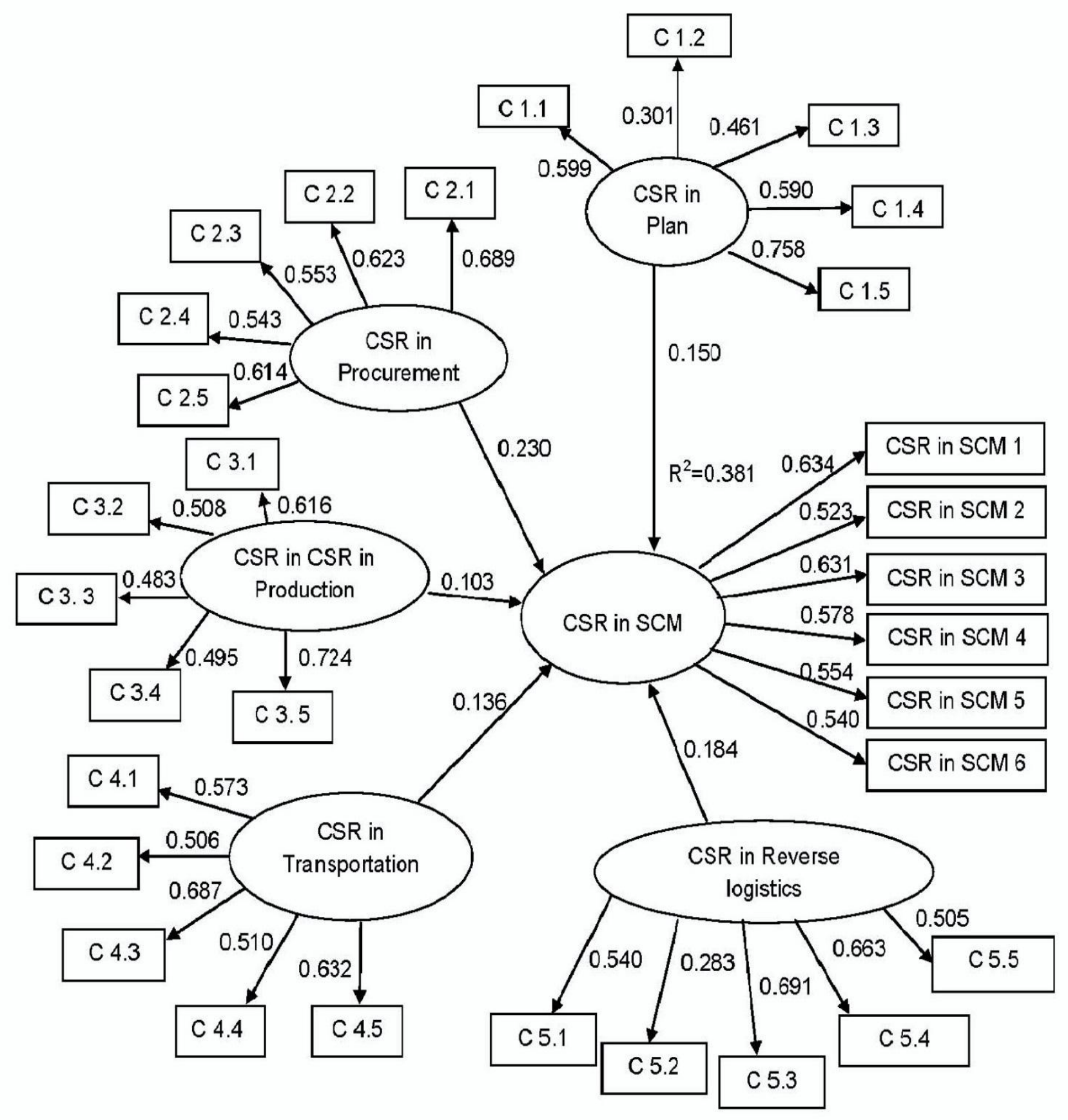

Figure 2 The structural equation model of CSR in SCM

Table 3 Hypothesis testing

\begin{tabular}{ccccc}
\hline \multicolumn{1}{c}{ Path } & $\begin{array}{c}\text { Path } \\
\text { coefficient }\end{array}$ & t-test & p-value & results \\
\hline H1: C1 $\rightarrow$ CSR in SCM & 0.150 & $2.272^{* *}$ & 0.023 & Support \\
H2: C2 $\rightarrow$ CSR in SCM & 0.230 & $1.691^{*}$ & 0.091 & Support \\
H3: C3 $\rightarrow$ CSR in SCM & 0.103 & $2.904^{* *}$ & 0.004 & Support \\
H4: C4 $\rightarrow$ CSR in SCM & 0.136 & $2.215^{*}$ & 0.025 & Support \\
H5: C5 $\rightarrow$ CSR in SCM & 0.184 & $3.603^{* *}$ & 0.000 & Support \\
\hline
\end{tabular}

$*$ p-value $<0.1, * *$ p-value $<0.05$ 
For the hypothesis testing, table 3 shows the path coefficients, t-test, and p-value to test whether there are relationships between dimensions and the CSR in the SCM. The results show that the using PLS analysis in the five hypotheses are supported as the p-values are less than 0.1. The C2 is the most important factor to the CSR in the SCM with a path coefficient of 0.230 followed by C5, C1, C4, and C3 with the path coefficients of $0.184,0.150,0.136$ and 0.103 , respectively

Table 4 Reliability and validity of the model

\begin{tabular}{ccccccc}
\hline Dimension & $\mathrm{R}^{2}$ & $\begin{array}{c}\text { Average } \\
\text { Communality }\end{array}$ & $\begin{array}{c}\text { Goodness of } \\
\text { fit }\end{array}$ & CR & AVE & $\begin{array}{c}\text { Cronbach's } \\
\text { alpha }\end{array}$ \\
\hline CSR in SCM & 0.381 & 0.276 & 0.325 & 0.713 & 0.333 & 0.516 \\
\hline
\end{tabular}

Table 4 presents the reliability and validity of the model. The $\mathrm{R}^{2}$ of the model is 0.381 which is more than 0.2 . This means that the CSR in SCM is well explained by the five dimensions. The goodness of fit value is 0.325 which is less than 1. This shows that the model is significantly fit to the data. The average CR is 0.713 which is above 0.7 representing high reliability. The average variance extraction (AVE) is 0.333 which is less than 0.5 and the average Cronbach's alpha is 0.516 which is less than 0.7 . These show that the dimensions are fairly well represented by their indicators.

Table 5Dimensions and indicators, confirmatory factor analysis, and reliability measures for the reflective constructs

\begin{tabular}{|c|c|c|c|c|c|c|}
\hline Indicators & $\begin{array}{c}\text { Mean } \\
(1-5)\end{array}$ & Sd. & $\begin{array}{l}\text { CFA } \\
\text { loading }\end{array}$ & $\begin{array}{l}\text { Cronbach's } \\
\text { alpha }\end{array}$ & AVE & $\begin{array}{l}\text { Composite } \\
\text { reliability }\end{array}$ \\
\hline \multicolumn{7}{|l|}{ 1.CSR in Plan (C1) } \\
\hline $\begin{array}{l}\text { C1.1 SCM activities planning } \\
\text { with consideration to human } \\
\text { rights. }\end{array}$ & 3.70 & 0.68 & 0.599 & 0.479 & 0.317 & 0.683 \\
\hline $\begin{array}{l}\text { C1.2 SCM activities planning } \\
\text { by eliminating of compulsory } \\
\text { labor and child labor. }\end{array}$ & 3.47 & 0.64 & 0.301 & & & \\
\hline $\begin{array}{l}\text { C1.3 SCM activities planning } \\
\text { by reducing environmental } \\
\text { effects. }\end{array}$ & 3.85 & 0.73 & 0.461 & & & \\
\hline $\begin{array}{l}\text { C1.4 SCM activities planning } \\
\text { by using friendly technologies. }\end{array}$ & 3.74 & 0.76 & 0.590 & & & \\
\hline $\begin{array}{l}\text { C1.5 SCM activities planning } \\
\text { by resisting corruption. }\end{array}$ & 3.62 & 0.70 & 0.758 & & & \\
\hline Average & 3.68 & 0.71 & & & & \\
\hline \multicolumn{7}{|l|}{ 2.CSR in Procurement (C2) } \\
\hline $\begin{array}{l}\text { C2.1 Procurement practice with } \\
\text { procurement justice. }\end{array}$ & 3.50 & 0.71 & 0.689 & 0.571 & 0.368 & 0.743 \\
\hline $\begin{array}{l}\text { C2.2 Procurement process by } \\
\text { selecting suppliers that eliminate } \\
\text { compulsory labor and child labor. }\end{array}$ & 3.48 & 0.91 & 0.623 & & & \\
\hline $\begin{array}{l}\text { C2.3 Procurement process by } \\
\text { selecting green suppliers. }\end{array}$ & 3.63 & 0.68 & 0.623 & & & \\
\hline $\begin{array}{l}\text { C2.4 Procurement management } \\
\text { by selecting friendly- } \\
\text { technologies suppliers. }\end{array}$ & 3.60 & 0.70 & 0.553 & & & \\
\hline $\begin{array}{l}\text { C } 2.5 \text { Procurement operation by } \\
\text { resisting corruption. }\end{array}$ & 3.43 & 0.86 & 0.614 & & & \\
\hline Average & 3.53 & $\mathbf{0 . 7 8}$ & & & & \\
\hline \multicolumn{7}{|l|}{ 3.CSR in Production $(\mathrm{C3})$} \\
\hline $\begin{array}{l}\text { C3.1 Production practice with } \\
\text { employees' rights }\end{array}$ & 3.56 & 0.86 & 0.617 & 0.483 & 0.328 & 0.704 \\
\hline $\begin{array}{l}\text { C } 3.2 \text { Production process by } \\
\text { eliminating compulsory labor } \\
\text { and child labor. }\end{array}$ & 3.56 & 0.67 & 0.507 & & & \\
\hline
\end{tabular}


C3.3 Production process by reducing environmental effects. C3.4 Production management by using friendly technologies. C3.5 Production operation with by resisting corruption.

\begin{tabular}{|c|c|c|c|c|c|c|}
\hline Average & 3.61 & 0.75 & & & & \\
\hline \multicolumn{7}{|l|}{ 4.CSR in Transportation (C4) } \\
\hline $\begin{array}{l}\text { C4.1 Transportation practice } \\
\text { with employees' rights. }\end{array}$ & 3.73 & 0.77 & 0.573 & 0.526 & 0.343 & 0.720 \\
\hline $\begin{array}{l}\text { C4.2 Transportation process by } \\
\text { eliminating compulsory labor } \\
\text { and child labor. }\end{array}$ & 3.71 & 0.83 & 0.506 & & & \\
\hline $\begin{array}{l}\text { C4.3 Transportation process by } \\
\text { reducing environmental effects. }\end{array}$ & 3.71 & 0.63 & 0.687 & & & \\
\hline $\begin{array}{l}\text { C4.4 Transportation } \\
\text { management by using friendly } \\
\text { technologies }\end{array}$ & 3.63 & 0.76 & 0.510 & & & \\
\hline $\begin{array}{l}\text { C4.5 Transportation operation } \\
\text { by resisting corruption. }\end{array}$ & 3.66 & 0.70 & 0.632 & & & \\
\hline Average & 3.69 & 0.74 & & & & \\
\hline \multicolumn{7}{|l|}{ 5.CSR in Reverse logistics (C5) } \\
\hline $\begin{array}{l}\text { C5.1 Reverse logistics practice } \\
\text { with adherence to ethical } \\
\text { trading. }\end{array}$ & 3.60 & 0.65 & 0.540 & 0.458 & 0.376 & 0.704 \\
\hline $\begin{array}{l}\text { C } 5.2 \text { Reverse logistics process } \\
\text { by eliminating }\end{array}$ & 3.73 & 0.69 & 0.283 & & & \\
\hline \multicolumn{7}{|l|}{$\begin{array}{l}\text { Compulsory labor and child } \\
\text { labor. }\end{array}$} \\
\hline $\begin{array}{l}\text { C5.3 Reverse logistics process } \\
\text { by reducing environmental } \\
\text { effects. }\end{array}$ & 3.59 & 0.70 & 0.691 & & & \\
\hline $\begin{array}{l}\text { C5.4 Reverse logistics } \\
\text { management by using friendly }\end{array}$ & 3.58 & 0.92 & 0.663 & & & \\
\hline $\begin{array}{l}\text { technologies. } \\
\text { C5.5 Reverse logistics } \\
\text { operation by resisting } \\
\text { corruption. }\end{array}$ & 3.58 & 0.83 & 0.505 & & & \\
\hline Average & 3.62 & 0.76 & & & & \\
\hline \multicolumn{7}{|l|}{ *CSR in SCM } \\
\hline $\begin{array}{l}\text { Improving suppliers' } \\
\text { collaboration. }\end{array}$ & 3.56 & 0.74 & 0.634 & 0.479 & 0.317 & 0.750 \\
\hline Improving product quality. & 3.65 & 0.82 & 0.523 & & & \\
\hline $\begin{array}{l}\text { Improving customers' } \\
\text { expectations. }\end{array}$ & 3.77 & 0.73 & 0.631 & & & \\
\hline Reducing the SCM risk. & 3.78 & 0.71 & 0.578 & & & \\
\hline $\begin{array}{l}\text { Maintaining employees' and } \\
\text { customers' relationship. }\end{array}$ & 3.76 & 0.73 & 0.554 & & & \\
\hline Creating new market. & 3.72 & 0.70 & 0.540 & & & \\
\hline Average & 3.71 & 0.74 & & & & \\
\hline
\end{tabular}

$\begin{array}{lll}3.71 & 0.74 & 0.482\end{array}$

$\begin{array}{lll}3.67 & 0.75 & 0.495\end{array}$

$\begin{array}{lll}3.58 & 0.69 & 0.724\end{array}$ 
The confirmatory factor loading of SCM activities planning by eliminating compulsory labor and child labor (loading=0.301) and by reducing environmental effects (loading=0.461) indicated loading at less than 0.5 indicating it was neither an important nor less important indicator for explaining the CSR in planning. SCM activities planning with resisting corruption had the greatest loading in this dimension which explains the important indicators of CSR in planning. The remaining, two indicators that includes SCM activities planning with consideration to human rights, and by using friendly technologies are presented as highly important describing them as dimension indicators.

In the second dimension, CSR in procurement was shown to have an average mean of importance level at $3.53 \quad(\mathrm{Sd} .=$ 0.78), of which respondents agreed that this dimension was divided into the important dimension of CSR in SCM. The indicator average mean of important levels was between 3.43 - 3.63 indicating that giving details in the CSR in procurement was important. All indicators were confirmed by factor loading greater than 0.5 and presented a good explanation for CSR in procurement. In the third dimension, CSR in production, the average mean importance level of the CSR in production was $3.61(\mathrm{Sd} .=0.75)$. The indication of respondents agrees that CSR in production is an important dimension, was relevant to CSR in SCM. The confirmatory indication of the production process by reducing of environmental effects (loading=0.482) and by using friendly technologies (loading=0.495) was less than 0.5 indicating it was neither an important nor less important indicator for explaining the CSR in production. The indicator of production practice with emphasis on employees' rights by eliminating of compulsory labor and child labor and with resisting of corruption was at a high importance indicator for explaining dimension indicating.

In the fourth dimension, the average mean importance level of CSR in transportation was at 3.69 (Sd. $=0.74)$. The respondents shared the same opinion that CSR in planning is an important dimension consequence to CSR in SCM. The indicator average mean of important levels between 3.63 - 3.73 indicated strongly to make clear the CSR in transportation. All indicators were confirmed by factor loading of greater than 0.5 and which presented excellent explanation to CSR in transportation. In the last dimension, the average mean of importance level of CSR in reverse logistics was $3.62(\mathrm{Sd} .=0.76)$. The respondents indicate to this dimension which is important effecting to CSR in SCM. The indicator average mean of importance levels between 3.58-3.73 indicated highly the effect to the CSR in reverse logistics. The indication of CSR in reverse logistics processes by eliminating compulsory labor and child labor (loading=0.283) was less than 0.5 indicating it was neither an important nor non-important indicator to explain this dimension. Additionally, four indicators remaining CSR in reverse logistics were confirmed by factor loading more than 0.5 which presented a well explanation to this dimension. In addition, the indicating explanation of CSR in SCM dimension showed six indicators and the average mean of importance level of this dimension was $3.71(\mathrm{Sd}$. $=0.74)$. All indicators of this dimension were confirmed by factor loading greater than 0.5 which were presented well giving the benefits explanation of CSR in SCM.

CSR in SCM is the most challenging in the industrial sector and does not have practical guidelines for operational planning (Missimer, Robert \& Broman, 2017). This principle model of CSR in SCM supports both academic and industry contribution. In academic manner, the findings show the integration of CSR and SCM concept which explains knowledge about the structural guideline of CSR in SCM towards sustainable supply chain. In industry manner, the five dimensions and 31 indicators of the CSR in SCM, it appears the model fits well to the research data. Therefore, auto part manufacturers wishing to improve their CSR in SCM practices need to constantly monitor their indicators. The measurement scale validated in this work can be used as a self-diagnostic tool to identify areas where specific improvement is needed. The five main dimensions of CSR in SCM need first to be practiced for achieving corporate sustainability to CSR policy, SCM strategies, and cultural organizations as well. When companies input these dimensions and indicators to operations affecting the benefits of CSR in SCM, these companies will achieve improving suppliers' collaboration, improving product quality, improving customers' expectations, reducing the SCM risk, maintaining employees' and customers' relationship, and creating new markets which are the main implement to create social responsibility, environmental friendliness and value adding in a chain (Popovic, Carvalho, Kraslawski\&Povoa, 2016; Mani, Gunasekaran \& Delgado, 2018).

\section{Conclusion}

CSR is a significant challenge of SCM in business management. This research is to test the conceptual framework for developing a principle model of CSR in SCM. The research results covered the five key dimensions of CSR in SCM and dimensions indicating which CSR in SCM model presented the principle of corporate sustainability. The Thai auto parts industry based in Amata Nakorn Chonburi, Thailand was focused on in this case study. The conceptual framework of the main dimensions and indicators of CSR in SCM was concluded by academic literature and CSR documents. This framework integrated the elemental knowledge of the SCOR model and focused on corporate sustainability in the five main dimensions from UN Global Compact. After that, the conceptual framework of CSR in SCM was tested by the structural equation model using the partial least square (PLS-SEM). 
The sample size of 248 officers comprising the population were randomly selected using the cluster sampling method and were chosen because they were working in fields related to the ISO 14001 and TS16949 departments and the SCM department. The findings indicated that the structural equation model of CSR in SCM was moderately strong. The hypothesis testing, the path coefficients, t-test, and p-value were tested to determine whether there was a relationship between the dimensions and the CSR in SCM. The results showed that using PLS analysis for the five hypotheses was supported as the p-values were less than 0.1. For the loading values of the indicators in five dimensions, it can be seen that most loadings were greater than 0.5 and the indicators explain moderately well their own dimensions. From the descriptive statistics, we can see that the importance levels of the indicators to the dimensions are at a middle level. This principle model of CSR in SCM should be applied to operational planning on policy, strategy, and performance indication. The company can manage all indicators of these dimensions to strong operational planning for achieving the key benefits of CSR in SCM. However, this research has a limitation to the primary model and first guideline of cooperate sustainability. Future research can improve this finding to become a complete model of supply chain sustainability and applied to other industrial sectors.

\section{References}

Aigner, D.J., \&Lloret, A. (2013). Sustainability and competitiveness in Mexico. Management Research Review, 36(12), 1252-1271.

Andersen, M., \&Skjoett-Larsen, T. (2009). Corporate social responsibility in global supply chains. Supply Chain Management: An International Journal, 14(2), 75-86.

APICS.(2017). Supply Chain Operations Reference (SCOR) model. Retrieved January 20, 2018 from http://www.apics.org/apics-for-business/frameworks/scor.

Bak, O., \&Boulocher-Passet, V. (2013). Connecting industry and supply chain management education: exploring challenges faced in a SCM consultancy module. Supply Chain Management: An International Journal, 18(4), $468-479$.

Banterle, A., Cereda, E., \& Fritz, M. (2013). Labelling and sustainability in food supply networks: A comparison between the German and Italian markets. British Food Journal, 115(5), 769-783.

Bevilacqua, M., Ciarapica, F.E., \&Giacchetta, G. (2012). Design for environment as a tool for the development of a sustainable supply chain. NewYork : Springer.

Biedenweg, K., Monroe, M.C., \&Oxarart, A. (2013). The importance of teaching ethics of Sustainability. International Journal of Sustainability in Higher Education, 14(1), 6-14.

Blunch, N.J. (2013). Introduction to structural equation modeling using IBM SPSS and AMOS. LosAngeles : SAGE.

Bouzaabia, O., Riel, A.C.R., \&Semeijn, J. (2013). Managing in-store logistics: a fresh perspective on retail service. Journal of Service Management, 24(2), 112-129.

Chen, Z., \& Tan, K.H. (2013). The impact of organization ownership structure on JIT implementation and production operations performance. International Journal of Operations\& Production Management, 33(9), 1202-1229.

Clark, J.W., Toms, L.C., \& Green, K.W. (2014). Market-oriented sustainability: moderating impact of stakeholder Involvement. Industrial Management \& Data Systems, 114(1), 21-36.

Cruz, L.B, \&Boehe, D.M. (2008). CSR in the global marketplace. Management Decision,46(8), 1187-1209.

Dade, A., \&Hassenzahl, D.M. (2013). Communicating sustainability A content analysis of website communications in the United States. International Journal of Sustainability in Higher Education, 14(3), 254-263.

Figueredo, F.R., \&Tsarenko, Y. (2013). Is "being green" a determinant of participation in university sustainability initiatives?. International Journal of Sustainability in Higher Education, 14(3), 242-253.

Gold, S. (2014). Supply chain management as Lakatosian research program. Supply Chain Management: An International Journal, 19(1), 1-9.

Han, J., Lu, H., Trienekens, J.H., \&Omta, S.W.F. (2013). The impact of supply chain integration on firm performance in the pork processing industry in China. Chinese Management Studies, 7(2), 230-252.

Hernandez, J.A., \&Melis, A. (2018). Understanding the temporary appropriation in relationship to social sustainability. Sustainable Cities and Society, 39, 366-374.

Hugos, M. (2011). Essentials of supply chain management. Hoboken,N.J. : JohnWiley\&Sons. International Organization for Standardization. (2018). ISO 14000 family - Environmental management and ISO 26000 Social responsibility. Retrieved November 14, 2018 from https://www.iso.org/home.html

Kelloway, E.K.(2015). Using Mplus for structural equation modeling: a researcher's guide. LosAngeles : SAGE.

Mani, V., \&Gunasekaran, A. (2018). Four forces of supply chain social sustainability adoption in emerging economies. International Journal of Production Economics, 199, 150-161. 
Mani, V., Gunasekaran, A., \& Delgado. C. (2018). Enhancing supply chain performance through supplier social sustainability: An emerging economy perspective. International Journal of Production Economics, 195, 259272.

Mani, V., Gunasekaran, A., \& Delgado. C. (2018). Supply chain social sustainability: Standard adoption practices in Portuguese manufacturing firms. International Journal of Production Economics, 198, 149-164.

Missimer, M., Robert, K.H., \& Broman, G. (2017). A strategic approach to social sustainability - Part 1: exploring the social system. Journal of Cleaner Production, 140, 1, 32-41.

Muangpan, T., Chaowarat, M.,\&Neamvonk, J. (2014). A Framework of Performance for Sustainable Supply chain Management: Thai cement industry. World Journal of Social Sciences, 4(3), 24-38.

Morana, J. (2013). Sustainable supply chain management. London : ISTE.

Nalband, N.A., \& Al-Amri, M.S. (2013). Corporate social responsibility. Competitiveness Review: An International Business Journal, 23(3), 284-295.

Popovic, T., Carvalho, A., Kraslawski, A., \&Póvoa, A.B. (2016). Framework for assessing social sustainability in supply chains. Computer Aided Chemical Engineering, 38, 2019-2024.

Ringle, Christian, M., Wende, S., \& Becker, M. (2015). SmartPLS 3.Bönningstedt: SmartPLS. Retrieved January 20, 2018 from http://www.smartpls.com.

Thailand's automotive industry the next-generation. (2015). Thailand Board of Investment. Retrieved January 20, 2018 from http://www.boi.go.th.

The Benefits of corporate social responsibility in Supply Chain. (2018). Retrieved March 9, 2018 from http://www.csrcompass.com.

United Nations Environment Programme. (2011). UNEP 2010 ANNUAL REPORT.Published: February 2011. ISBN: 978-92-807-3149-1 Job number: DCP/1354/NA.

United Nations Environment Programme. (2016). UNEP 2015 ANNUAL REPORT.Publication: UNEP 2015 Annual Report ISBN: 978-92-807-3518-5 Job No: DCP/1938/NA.

United Nations Global Compact. (2018).Ten principles of corporate social responsibility. Retrieved January 10, 2018 from http://www.unglobalcompact.org.

Wisner, J.D., Tan, K.C., \& Leong, G.K. (2012). Supply chain management : a balanced approach. Australia : SouthWesternCengageLearning.

Wu, X. \&Zhi, Q. (2016). Impact of Shared Economy on Urban Sustainability: from the Perspective of Social, Economic, and Environmental Sustainability. Energy Procedia, 104, 191-196.

Xia, Y. \& Tang, T.L.P. (2011). Sustainability in supply chain management: suggestions for the auto industry. Management Decision, 49(4), 495-512. 